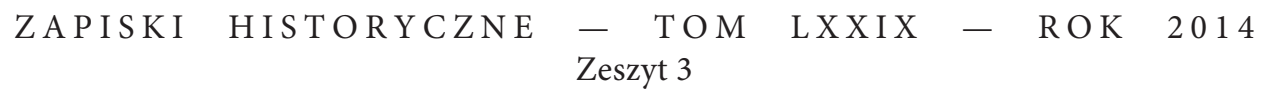

http://dx.doi.org/10.15762/ZH.2014.03

DARIUSZ BURCZYK (Gdańsk)

\title{
UDZIAŁ SPECJALNEGO SĄDU KARNEGO W GDAŃSKU I JEGO PROKURATURY W PROCESIE WERYFIKACJI I REHABILITACJI LUDNOŚCI POMORZA GDAŃSKIEGO W LATACH 1945-1946
}

Słowa kluczowe: niemiecka lista narodowa, polskie sądownictwo powojenne, dekrety państwowe, wysiedlenia ludności niemieckiej, tzw. zdrajcy narodu polskiego

W polskiej historiografii ukazało się dotychczas niewiele prac poświęconych w całości lub w znacznej części organizacji i funkcjonowaniu sądownictwa specjalnego w Polsce, które na mocy dekretu Polskiego Komitetu Wyzwolenia Narodowego (dalej cyt. PKWN) z 31 VIII 1944 r. o wymiarze kary dla faszystowsko-hitlerowskich zbrodniarzy winnych zabójstw, znęcania się nad ludnością cywilną i jeńcami oraz dla zdrajców narodu polskiego ${ }^{1}$ zostało powołane w celu ścigania i osądzenia zbrodni popełnionych w czasie okupacji przez nazistów oraz osoby z nimi współpracujące ${ }^{2}$. Jeszcze mniej uwagi badacze poświęcili dotychczas udzia-

${ }^{1}$ Dziennik Ustaw (dalej cyt. DzU) z 1944 r., Nr 4, poz. 16.

${ }^{2}$ Szerzej zob. w: Janina Wojciechowsкa, Przestępcy hitlerowscy przed Specjalnym Sadem Karnym $w$ Toruniu (1945-1946), Studia Iuridica, t. 6: 1965, z. 2, s. 1 n.; Kazimierz BogUcKi, Organizacja i funkcjonowanie Prokuratury Specjalnego Sądu Karnego w Gdańsku (1945-1946), Rocznik Słupski, [R.] 3: 1981, s. 30-56; idem, Ściganie i karanie hitlerowskich zbrodniarzy wojennych w Polsce Pótnocnej (1945-1946), ibid., [R.] 2: 1980, s. 179-193; idem, Z badań nad działalnością Specjalnego Sadu Karnego w Gdańsku (1945-1946), Koszalińskie Studia i Materiały, 1973, nr 2, s. 235-247; Zdzisław BIEgAŃsKi, Kara śmierci w orzecznictwie specjalnych sąów karnych w Polsce (1944-1946), Echa Przeszłości, [t.] 5: 2004, s. 175-200; Marek Żukowsкi, Organizacja i działalność Specjalnego Sadu Karnego w Gdańsku 1945-1946, [in:] IV Ogólnopolskie Forum Historyków Wojskowych, Koszalin, 16 XII 1998, red. Bogusław PolaK, Koszalin 1999, s. 317-332; Elżbieta Kobierska-Motas, Ściganie sprawców zbrodni hitlerowskich przez polski aparat wymiaru sprawiedliwości w latach 1944-1950, [in:] W czterdziestolecie powołania Najwyższego Trybunału Narodowego. Materiały z posiedzenia naukowego w dniu 20 stycznia 1986 r., Warszawa 1986, s. 23-36; eadem, Karanie sprawców zbrodni hitlerowskich przez sądy południowo-wschodnich terenów Polski, Rocznik Historyczno-Archiwalny, t. 5: 1988, s. 105-124; Czesław PILICHowski, Zasady Norymberskie a sprawa ścigania i karania hitlerowskich zbrodniarzy wojennych (1945-1971), Sprawy Międzynarodowe, R. 24: 1971, nr 11, s. 28-29; idem, Udział Polski w badaniu i ściganiu zbrodni hitlerowskich, [in:] Zbrodnie i sprawcy. Ludobójstwo hitlerowskie przed sądem ludzkości i historii, red. idem, Warszawa 1980, s. 23-87; Adalbert RücKeRL, Ściganie zbrodni hitlerowskich 1945-1978, tłum. Włodzimierz Hanczakowski, Warszawa 1980; Jerzy SAwICKI, O prawie sądów specjalnych - próba metodyczna, [in:] Wymiar sprawiedliwości w odrodzonej Polsce 22 VII 1944 - 22 VII 1945, Warszawa 1945, s. 55-64; Tadeusz Cyprian, Jerzy Sawicki, Pra- 
łowi specjalnych sądów i prokuratur karnych w postępowaniu rehabilitacyjnym, któremu po zakończeniu drugiej wojny światowej poddano w całej Polsce setki tysięcy osób ${ }^{3}$. Poważny udział w tych działaniach miały także Specjalny Sąd Karny (dalej cyt. SSK) w Gdańsku oraz współpracująca z nim prokuratura.

Złożona sytuacja narodowościowa na wyzwolonych spod niemieckiej okupacji terenach Pomorza Gdańskiego postawiła przed będącą jeszcze w stadium organizacyjnym administracją państwową pilną potrzebę uregulowania podstawowych kwestii prawnych i własnościowych zamieszkujących ten obszar osób narodowości niemieckiej oraz takich, które z różnych powodów przyjęły niemieckie obywatelstwo podczas okupacji ${ }^{4}$. Na podstawie zarządzenia Ministerstwa Administracji Państwowej (dalej cyt. MAP) z 20 VI 1945 r. pełnomocnicy rządu zostali upoważnieni do wydawania tymczasowych (trzymiesięcznych) zaświadczeń umożliwiających korzystanie z praw przysługujących obywatelom Rzeczypospolitej tym obywatelom byłej Rzeszy Niemieckiej, którzy: zamieszkiwali w dniu 31 VIII 1939 r. na terenach nowo odzyskanych ziem polskich, należeli do narodowości polskiej, nie byli członkami Narodowosocjalistycznej Niemieckiej Partii Robotników (dalej cyt. NSDAP), nie popełnili przestępstw opisanych w dekrecie z 31 VIII $1944 \mathrm{r}$. i złożyli pisemne deklaracje wierności narodowi polskiemu ${ }^{5}$.

$\mathrm{Na}$ terenie województwa gdańskiego upoważnionym do wydawania tymczasowych zaświadczeń został wojewoda gdański, który zlecił to zadanie starostom powiatowym i prezydentom miast Gdańska, Sopotu i Gdyni'. Utworzono

wo polskie $w$ walce $z$ hitleryzmem i kolaboracjonizmem, Demokratyczny Przegląd Prawniczy, 1946, nr 11-12, s. 13-22; iidem, Siedem wyroków Najwyższego Trybunału Narodowego, Warszawa 1962; iidem, Walka o zasady norymberskie 1945-1955, Warszawa 1956; Tadeusz GaszToLD, Przed polskim sqadem... ( $Z$ dziejów prześladowań polskich robotników przymusowych na ziemi koszalińskiej w latach 1939-1945), Zapiski Koszalińskie, 1965, z. 4, s. 56-64.

${ }^{3}$ Wyjątek w tej kwestii stanowi praca Sylwii Bykowskiej poświęcona właśnie procesowi rehabilitacji i weryfikacji ludności Pomorza Gdańskiego, jednak nawet w tym opracowaniu udział w całym procesie SSK w Gdańsku i podległej mu prokuratury nie został w dostateczny sposób zbadany i opisany. Szerzej zob. Sylwia BүкоwsкA, Rehabilitacja i weryfikacja narodowościowa polskiej ludności w województwie gdańskim po II wojnie światowej, Gdańsk 2012. Cenne uzupełnienie wspomnianej pracy stanowi jej recenzja autorstwa Stanisława Salmonowicza (zob. Stanisław SALMONOwicz, O losach ludności rodzimej Pomorza Gdańskiego w latach 1939-1950, Acta Cassubiana, t. 15: 2013, s. 263-277).

${ }^{4}$ Ludność na Pomorzu wpisywano do jednej z czterech grup. Pod koniec wojny na niemiecką listę narodową wpisano około 937000 osób (odpowiednio: w grupie pierwszej - 115000 osób, w grupie drugiej - 95 000, w grupie trzeciej - 725000 i w grupie czwartej - 2000). Szerzej zob. Włodzimierz JastrZęBSki, Polityka narodowościowa w Okręgu Rzeszy Gdańsk-Prusy Zachodnie (1939-1945), Bydgoszcz 1977; Julian Rados, Rehabilitacja na Pomorzu Gdańskim, Gdańsk 1969.

${ }^{5}$ Robert Sковецsкi, Ziemie Zachodnie i Północne Polski w okresie realizacji planu sześcioletniego 1950-1955, Zielona Góra 2002, s. 27-28.

${ }^{6}$ W dniu 6 IV 1946 r. Ministerstwo Ziem Odzyskanych (dalej cyt. MZO) wydało zarządzenie dotyczące trybu stwierdzania polskiej przynależności narodowej osób zamieszkałych na terenach „poniemieckich”. Kilka tygodni później (28 kwietnia) kwestię uznania obywatelstwa polskiego rozstrzygnęła ostatecznie uchwała Krajowej Rady Narodowej o obywatelstwie Państwa Polskiego osób narodowości polskiej zamieszkałych na obszarze „Ziem Odzyskanych”. Na podstawie obydwu wy- 
komisje składające się z przedstawiciela administracji ogólnej pierwszej instancji jako przewodniczącego, dwóch reprezentantów rady narodowej lub w razie ich braku przedstawicieli stronnictw politycznych, Polskiego Związku Zachodniego lub związków zawodowych oraz od trzech do pięciu reprezentantów miejscowej ludności . W skład Wojewódzkiej Komisji Weryfikacyjnej mającej dokonać weryfikacji ludności zamieszkującej województwo gdańskie weszli m.in. Stanisław Romanowski, Wiktor Roszczynialski, Bronisław Bukowski i Mirosław Dybowski ${ }^{8}$. Do lipca 1946 r. w województwie gdańskim zweryfikowano pozytywnie 32000 osób?

Przewodniczący SSK w Gdańsku Józef Tarczewski twierdził, że komisje rozpatrujące wnioski o wydanie tymczasowych zaświadczeń przyjmowały zawarte w nich informacje bez większych zastrzeżeń, a świadków przesłuchiwano tylko w nielicznych wypadkach. Decydującym momentem podczas wydawania zaświadczeń, według J. Tarczewskiego, była decyzja członków komisji oparta na ich wewnętrznym przekonaniu. W tych warunkach jakakolwiek kontrola ze strony władz bezpieczeństwa lub prokuratury SSK, która z zasady nie była powiadamiana o przebiegu i wynikach procesu weryfikacji, była praktycznie niemożliwa. Według J. Tarczewskiego czasami dochodziło do sytuacji, w których zaświadczenia wydawano całym rodzinom, nawet gdy tylko jeden z członków rodziny mówił trochę po polsku ${ }^{10}$.

Zaobserwowano wówczas pojawienie się wśród miejscowych Niemców wyrażenia „einpolonisieren”. Tacy „polonizujący” się Niemcy bardzo często byli w lepszej sytuacji od osób pochodzenia polskiego wpisanych za czasów okupacji do drugiej grupy listy narodowości niemieckiej. J. Tarczewski poruszając to zagadnienie podczas rozmowy z urzędnikiem Wydziału Społeczno-Politycznego Urzędu Wojewódzkiego Gdańskiego (dalej cyt. UWG), został zapewniony, że ta kwestia jest znana „czynnikom decyzyjnym” i w najbliższym czasie zostanie wydane zarządzenie umożliwiające kierowanie zażaleń od orzeczeń komisji do prokuratury SSK. Poza tym przewodniczącego gdańskiego SSK niepokoiła sprawa wydawania dowodów osobistych polskim repatriantom z Niemiec, którzy na podstawie zaświadczeń granicznych placówek Państwowego Urzędu Repatriacyjnego otrzymywali dowody w którymkolwiek ze starostw, gdzie byli praktycznie nieznani. W związku

mienionych aktów prawnych głównym organem uprawnionym do stwierdzania przynależności narodowej stawały się władze administracji ogólnej pierwszej instancji (tj. powiatowe), które zostały zobowiązane do nadania obywatelstwa polskiego wszystkim osobom, które udowodniły je przed komisjami weryfikacyjnymi (zob. Patrycy DzıURzyński, Osadnictwo rolne na Ziemiach Odzyskanych, Warszawa 1983, s. 228).

${ }^{7}$ S. Вукошsка, op.cit., s. 209.

${ }^{8}$ Ibid., s. 358.

${ }^{9}$ Witold Stankowski, Niemcy na Pomorzu Gdańskim i Kujawach w latach 1944/45-1950. Ucieczka, życie codzienne, wysiedlenie, Bydgoszcz 2000, s. 148. Nieco inne dane podaje S. Bykowska, według której do 15 IX 1946 r. na terenie województwa gdańskiego zweryfikowano łącznie 30494 osoby (zob. S. ВукошsкA, op.cit., s. 428).

${ }^{10}$ Archiwum Akt Nowych (dalej cyt. AAN), Ministerstwo Sprawiedliwości (dalej cyt. MS), sygn. 7086, Sprawozdanie z działalności SSK w Gdańsku, [b.d.], k. 78. 
z tym mogło się zdarzyć, że tą drogą polskie dowody osobiste dostawały się w ręce osób, które jego zdaniem nie powinny przebywać na terenie Polski ${ }^{11}$.

Obok weryfikacji narodowościowej ${ }^{12}$ skomplikowanym zagadnieniem była sprawa niemieckiej listy narodowej ${ }^{13}$, na której znalazła się, nie mając na to wpływu, spora grupa ludności polskiej. Chodziło przede wszystkim o osoby z terenów włączonych w 1939 r. do Trzeciej Rzeszy: Górnego Śląska z Zagłębiem Dąbrowskim, zachodniej części województwa krakowskiego, Wielkopolski i części województwa łódzkiego, Pomorza i byłego Wolnego Miasta Gdańska, północnej części Mazowsza, Suwałk i Augustowa. Niezbyt fortunne zarządzenia władz w tym zakresie wydane w 1945 r. ${ }^{14}$ utrudniały rehabilitację nawet tym osobom, które pochodziły z obszarów, na których istniał przymus wpisu na niemiecką listę narodową (niem. Deutsche Volksliste, dalej cyt. DVL) i na volksliście znalazły się wbrew własnej woli. Sytuację pogarszał negatywny odbiór niemieckiej listy narodowej przez resztę społeczeństwa polskiego, szczególnie pochodzącego z Generalnego Gubernatorstwa, gdzie obecność na niej traktowano powszechnie jako zdradę. W celu sprawiedliwego przeprowadzenia procesu rehabilitacji osób umieszczonych na DVL postanowiono rozliczyć je nie za sam fakt wpisania na listę, lecz za ich postawę podczas okupacji, a każda sprawa miała zostać rozpatrzona indywidualnie ${ }^{15}$.

${ }^{11}$ Ibid., k. 78-79.

${ }^{12} \mathrm{~W}$ artykule Ani jednej krwi polskiej za Odrę. Uwagi na marginesie wadliwie prowadzonej akcji weryfikacyjnej opublikowanym 6 III 1946 r. w „Dzienniku Bałtyckim” jego autor przypominał, że na ziemiach polskich odbywały się w tym czasie równolegle dwa ważne procesy, które większości Polaków się myliły. Rehabilitacja polegała bowiem na przywróceniu osobom rehabilitowanym polskich praw obywatelskich, posiadanych przez nie przed wojną, natomiast weryfikacja miała na celu nadanie obywatelstwa polskiego tym osobom, które go nigdy nie miały, np. obywatelom Rzeszy z terenów Pomorza Zachodniego czy też byłym obywatelom Wolnego Miasta Gdańska. Autor zauważa również, że bardzo często pozytywne przejście procesu weryfikacji nie zapewniało zweryfikowanym bezpieczeństwa osobistego czy majątkowego, gdyż stanowili oni „obiekt nieustannych gwałtów, dokonywanych nie tylko przez zdemoralizowane masy szabrowników, ale niestety, częstokroć przez funkcjonariuszy państwowych" (Ani jednej krwi polskiej za Odrę. Uwagi na marginesie wadliwie prowadzonej akcji weryfikacyjnej, Dziennik Bałtycki, nr 64 z 6 III 1946 r.).

${ }^{13}$ Niemiecka lista narodowa powstała formalnie na mocy rozporządzenia z 4 III 1941 r., zamienionego następnie i uzupełnionego przez rozporządzenie z 31 I 1942 r. Obowiązywało ono na terenach polskich wcielonych do Rzeszy w 1939 r. i dzieliło polską ludność, która miała być poddana procesowi germanizacji, na cztery kategorie (grupy). Do pierwszej zaliczono osoby aktywne w walce narodowej po stronie niemieckiej przed wybuchem drugiej wojny światowej; do drugiej tych, którzy nie spełniali warunków określonych dla grupy pierwszej, ale zachowali swoją niemieckość; grupę trzecią miały tworzyć spolonizowane osoby pochodzenia niemieckiego, dające jednak gwarancję powrotu do niemieckości; do grupy czwartej włączono osoby pochodzenia niemieckiego, które choć spolonizowane, stanowiły rasowo wartościowy element do „regermanizacji” (zob. Edmund MĘCLEwski, Powrót Polski nad Odrę, Nysę Łużycką, Battyk, Warszawa 1971, s. 299-300).

${ }^{14}$ Chodzi o Dekret z 28 II 1945 r. o wyłączeniu ze społeczeństwa polskiego wrogich elementów (DzU z 1945 r., Nr 7, poz. 30) oraz Ustawę z 6 V 1945 r. o wyłączeniu ze społeczeństwa polskiego wrogich elementów (DzU z 1945 r., Nr 17, poz. 96).

${ }^{15}$ Archiwum Państwowe w Gdańsku (dalej cyt. APG), Urząd Wojewódzki Gdański (dalej cyt. UWG), sygn. 281, Pismo okólne MAP, 9 XI 1946 r., s. 55. 
Przewidywano dwie „ścieżki” rehabilitacji: administracyjną lub sądową. Jeżeli chodzi o pierwszą, to na mocy rozporządzenia MAP z 25 V 1945 r. osoby wpisane do trzeciej i czwartej grupy volkslisty zostały zobowiązane do złożenia w urzędach administracji państwowej pierwszej instancji deklaracji wierności narodowi i demokratycznemu państwu polskiemu ${ }^{16}$. W tym przypadku osobami odpowiedzialnymi za przebieg rehabilitacji byli prezydenci miast i starostowie powiatów. Koordynacją oraz kontrolą akcji rehabilitacyjnej zajmowały się Wydziały Społeczno-Polityczne poszczególnych urzędów wojewódzkich. Dodatkowo starostowie delegowali do poszczególnych gmin swoich pełnomocników, którzy prowadzili w terenie akcję rehabilitacyjną. Do ich obowiązków należały: prowadzenie rejestrów rehabilitacyjnych, współpraca $\mathrm{z}$ wydziałami ewidencji ludności, organami bezpieczeństwa publicznego, prokuraturami i sądami, sporządzanie instrukcji o sposobie prowadzenia rehabilitacji oraz informacji o przeprowadzonych rehabilitacjach ${ }^{17}$.

Odpisy rejestrów osób, które złożyły deklarację wierności, trafiały do kierowników miejscowych urzędów bezpieczeństwa publicznego, którzy mieli dopilnować, żeby wszystkie osoby zobowiązane do jej złożenia dopełniły tego obowiązku. Po upływie terminów, które miały zostać wskazane w rozporządzeniu wykonawczym, osoby trzeciej i czwartej grupy oraz grupy uprzywilejowanych Polaków, tzw. Leistungs-Polen, które nie złożyły deklaracji, powinny zostać zatrzymane przez organa bezpieczeństwa publicznego, a ich majątek należało tymczasowo zabezpieczyć i bezzwłocznie zawiadomić o tym urząd skarbowy, nadmieniając, że ma być on zabezpieczony do czasu wydania postanowienia przez sąd. Natychmiastowemu zatrzymaniu podlegały natomiast osoby, co do których wpłynęło doniesienie o posiadaniu przez nie w czasie okupacji jednej z grup volkslisty oraz te, co do których władze bezpieczeństwa dysponowały obciążającymi je materiałami. Ich majątek należało zabezpieczyć, a sprawę skierować do sądu grodzkiego. Podobna procedura obowiązywała w stosunku do osób wpisanych do drugiej i trzeciej grupy, mających na dowodach niemieckich pieczątkę "mit Verzicht auf den Wiederruf” (rezygnacja z odwołania), które należało traktować na równi z wpisanymi do drugiej grupy ${ }^{18}$.

Sylwia Bykowska wyróżniła trzy zasadnicze etapy procedury rehabilitacyjnej: złożenie deklaracji wierności narodowi i państwu polskiemu z poświadczeniem polskiego obywatelstwa posiadanego przed 1939 r., uzyskanie rehabilitacji potwierdzone zaświadczeniem tymczasowym oraz publiczne ogłoszenie danych

\footnotetext{
${ }^{16}$ DzU z 1945 r., Nr 21, poz. 128.

${ }^{17}$ S. BукошsKa, op.cit., s. 265-266.

${ }^{18}$ Instrukcja dyrektora departamentu w MBP z 9 IV 1945 r. o postępowaniu wtadz bezpieczeństwa na obszarach Rzeczypospolitej Polskiej włączonych w czasie okupacji do Rzeszy Niemieckiej i w Gdańsku $w$ stosunku do osób wymienionych $w$ dekrecie z 28 II 1945 r. o wyłaczeniu ze społeczeństwa polskiego wrogich elementów, [in:] Księga bezprawia. Akta normatywne kierownictwa Resortu Bezpieczeństwa Publicznego (1944-1956), opr. Bogusław Kopka, Warszawa 2011, s. 84-87.
} 
osobowych przez okres sześciu miesięcy, otrzymanie zaświadczenia stałego ${ }^{19}$. Na terenie województwa gdańskiego do końca 1945 r. deklarację wierności złożyło 126567 osób wpisanych do trzeciej i czwartej grupy DVL. Spośród tej grupy osób we wskazanym terminie zaświadczenia tymczasowe otrzymało 58355 osób ${ }^{20}$, natomiast 14121 osobom odmówiono rehabilitacji ${ }^{21}$. Pozostałe wnioski czekały na rozpatrzenie. Do końca stycznia 1946 r. liczba osób zrehabilitowanych administracyjnie w województwie gdańskim sięgnęła 138401 osób ${ }^{22}$.

Jeżeli chodzi o omawiany w pracy udział specjalnych sądów i prokuratur karnych w rehabilitacji sądowej osób, które w okresie drugiej wojny światowej zadeklarowały przynależność do narodowości niemieckiej, to na mocy przepisów dekretu PKWN z 4 XI 1944 r. o środkach zabezpieczających w stosunku do zdrajców Narodu ${ }^{23}$ prokurator SSK mógł takie osoby skierować np. do obozu pracy przymusowej $^{24}$. Z danych opublikowanych przez Kazimierza Boguckiego wynika, że od 1 X do 31 XII 1945 r. prokurator SSK w Gdańsku zarządził osadzenie w obozach 1211 osób, do 11 IX 1946 r. zaś takich osób było 759, co daje łączną liczbę 1970 osób osadzonych w obozach na podstawie decyzji prokuratura SSK w Gdańsku ${ }^{25}$.

Początkowo przepisy o środkach zabezpieczających objęły osoby z terenów Generalnego Gubernatorstwa oraz województwa białostockiego. W 1945 r. dekret zaczęto stosować także na terenach włączonych do Rzeszy, odnosząc jego regulacje m.in. do Kaszubów, Ślązaków i Mazurów, wobec których władze niemieckie często używały środków przymusu. W celu uporządkowania sytuacji prawnej tych osób władze zdecydowały w końcu o wydaniu pierwszych przepisów potwierdzających posiadanie polskiego obywatelstwa przez osoby zamieszkujące tereny włączone do Rzeszy i obszar Wolnego Miasta Gdańska, które zostały wpisane do trzeciej

${ }^{19}$ S. BYкоwsKA, op.cit., s. 303.

${ }^{20}$ Osoby zrehabilitowane otrzymywały ponownie pełnię praw obywatelskich, choć w wielu wypadkach ich sytuacja mimo rehabilitacji zmieniała się w niewielkim stopniu. Bez wsparcia administracji państwowej trudno było bowiem uświadomić członkom lokalnej społeczności, że są pełnoprawnymi obywatelami. Wiązało się to głównie z koniecznością wyrównania byłym „volksdeutschom” strat materialnych i oddania zagrabionych bezprawnie gospodarstw, co wywoływało nieraz olbrzymie niezadowolenie społeczne kierowane przeciwko zrehabilitowanym.

${ }^{21}$ Osoby, których wnioski rehabilitacyjne zostały odrzucone, osadzano w miejscach odosobnienia i nakładano na nie obowiązek pracy przymusowej, pozbawiając jednocześnie na zawsze praw obywatelskich i honorowych (zob. Anna Magierska, Ziemie zachodnie i północne w 1945 roku. Kształtowanie się podstaw polityki integracyjnej państwa polskiego, Warszawa 1978, s. 182). Do 1949 r. na terenach Polski (w granicach do 1939 r.) przejęto 98750 gospodarstw po „volksdeutschach” (zob. Paweł KACPRZAK, Weryfikacja narodowościowa ludności rodzimej i rehabilitacja tzw. „volksdeutschów” w latach 1945-1949, Czasopismo Prawno-Historyczne, t. 63: 2011, z. 2, s. 161).

${ }^{22} \mathrm{Z}$ tej liczby 1846 wnioski zostały rozpatrzone negatywnie. Zob. S. BykowsKA, op.cit., s. 308.

${ }^{23} \mathrm{DzU}$ z 1944 r., Nr 11, poz. 54.

${ }^{24}$ Słuszność decyzji prokuratora badał sąd na posiedzeniu niejawnym bez udziału osadzonego i obrońcy, utrzymując w mocy lub uchylając jego zarządzenie. Postanowienie sądu w tej kwestii nie podlegało zaskarżeniu (zob. Anna Machnıkowska, Wymiar sprawiedliwości w Polsce w latach 1944-1950, Gdańsk 2008, s. 266).

${ }^{25}$ K. Bogucki, Organizacja, s. 48. 
i czwartej grupy niemieckiej listy narodowej lub grupy Leistungs-Polen. Otwarto również drogę do rehabilitacji osób umieszczonych przez okupanta w drugiej grupie narodowej oraz w jednej z grup uprzywilejowanych ${ }^{26}$.

W jednym ze swoich miesięcznych sprawozdań dla Ministerstwa Sprawiedliwości (dalej cyt. MS) prokurator SSK w Gdańsku Stanisław Stachurski napisał: „W związku z koniecznością izolowania osób, których pozostawienie na wolności mogłoby zagrażać porządkowi prawnemu i bezpieczeństwu państwa, a którym na razie nie udowodniono żadnych konkretnych czynów przestępczych, jak członków NSDAP, SA, HJ i in., władze bezpieczeństwa zwracają się do Prokuratury o udzielenie sankcji na osadzenie tych osób w obozie pracy ${ }^{27}$. Mimo braku odpowiednich przepisów, które by na tym terenie uprawniały prokuratora Specjalnego Sądu Karnego do osadzania w obozach, sankcji takich udzielam"28.

Swoją decyzję w tym względzie prokurator S. Stachurski uzasadniał w następujący sposób: „Jak stwierdziłem, zwłaszcza we wsiach i mniejszych miastach członkowie NSDAP mieli duże wpływy, im to w dużej mierze przypisać należy akcje prześladowania ludności polskiej, nacisk do wpisywania się do narodowych list niemieckich itp. Uważam, że wszyscy członkowie tej partii winni być izolowani. Członków SA można, uważam podzielić na dwie grupy: aktywnych i należących do tzw. "wehrmanschaftu«; zadaniem tych ostatnich było na razie uczestniczenie w zebraniach oraz w odbywających się totalnych ćwiczeniach wojskowych; do tej grupy należało wielu eingedeutschów III grupy, przy czym niektórzy z nich do organizacji wstąpili jedynie pod przymusem. Sprawy tych ostatnich osób przekazuję w myśl art. 4 ustawy z dnia 6 maja [1945 r. - D.B.] do sądów grodzkich. Odpowiedzialność karną za przynależność do SA należy w myśl powyższego indywidualizować. Odnośnie członków HJ praktyka wykazuje, że byli oni przesiąknięci duchem hitleryzmu i przejawiali szczególną wrogość do polskości. Np. ostatnio sądzony 16 letni członek HJ wykazywał specjalną nienawiść do Polaków, a nawet szczycił się dokonanymi przez siebie zbrodniami na Polakach. Uważam, że winni

${ }^{26}$ Rozporządzenie wykonawcze MAP z 25 V 1945 r. wydane na podstawie przepisów ustawy z 6 V 1945 r. wyraźnie rozgraniczało osoby wpisane do trzeciej i czwartej grupy niemieckiej listy narodowej pochodzące z obszarów, na których Niemcy stosowali powszechny przymus przy wpisywaniu na volkslistę od osób z tych samych grup, lecz pochodzących z terenów, na których tego przymusu nie było. Byłe Wolne Miasto Gdańsk, w skład którego wchodziły: Gdańsk, Sopot, Pruszcz Gdański i Nowy Dwór Gdański, uznane zostało przez artykuł 1 ustawy „majowej” za obszar (podobnie jak Górny Śląsk i województwo pomorskie, z wyjątkiem kilku powiatów), na którym stosowano powszechny przymus w czasie wpisywania jego mieszkańców do trzeciej i czwartej grupy niemieckiej listy narodowej. W związku z tym obywatele byłego Wolnego Miasta Gdańska otrzymali z mocy ustawy pełnię praw obywatelskich, jeśli wpisani zostali do tych grup pod przymusem, a zachowaniem swoim wykazali polską odrębność narodową, zob. K. Bogucki, Organizacja, s. 46-47; Ryszard KozŁowski, Przeobrażenia społeczno-polityczne w województwie pomorskim (1945-1948), Toruń 1976, s. 17.

${ }^{27}$ Osadzonych w obozach zmuszano do ciężkiej pracy, często organizowanej w sposób nieracjonalny i nieefektywny, mającej charakter szykany. W latach 1944-1949 w takiej sytuacji było około 40-50\% skazanych na kary pozbawienia wolności, zob. A. MACHNikowsKA, op.cit., s. 351.

${ }^{28}$ AAN, MS, sygn. 7086, Sprawozdanie z działalności SSK w Gdańsku, [b.d.], k. 79. 
oni być również izolowani. Sprawy te jednak należy traktować indywidualnie, bowiem są częste wypadki, że dzieci eingedeutschów trzeciej grupy wciągane były do HJ pod presją. To samo dotyczy przynależności do BDM"29.

Osadzony w obozie pracy lub więzieniu ${ }^{30}$ tracił (z możliwością odzyskania w postępowaniu rehabilitacyjnym) wszelkie prawa publiczne, obywatelskie prawa honorowe oraz prawa rodzicielskie i opiekuńcze, a majątek jego i osób pozostających z nim we wspólnocie rodzinnej podlegał konfiskacie ${ }^{31}$. Więźniowie zmuszani byli do bardzo ciężkiej pracy, często mającej charakter represyjny. Administrację obozów, w których przebywały takie osoby, powierzono organom bezpieczeństwa publicznego. Prokuratorski nadzór nad ich funkcjonowaniem był iluzoryczny. Często osadzano w nich osoby bez wiedzy prokuratora ${ }^{32}$.

W tym czasie funkcjonariusze Urzędów Bezpieczeństwa Publicznego (dalej cyt. UBP) i Milicji Obywatelskiej (dalej cyt. MO) prowadzili dochodzenia w celu ustalenia tożsamości osadzonych, ich obywatelstwa, zachowania się w czasie okupacji, ewentualnego członkostwa w organizacjach nazistowskich, stosunku do społeczeństwa polskiego, a także stanu rodzinnego i stosunków majątkowych. Od wyników tego dochodzenia zależało, czy możliwe było zastosowanie wobec tych osób przepisów ustawy z 6 V 1945 r., nie można było bowiem traktować według nich tych, którzy w czasie okupacji: przypisani byli do pierwszej grupy niemieckiej listy narodowej i zostali zaliczeni do obywateli byłej Rzeszy, w związku z czym podlegali wysiedleniu z polskich „Ziem Odzyskanych”; zostali wpisani na niemiecką listę narodową na obszarze Generalnego Gubernatorstwa lub obszarach na wschód od rzeki Bug, gdyż w stosunku do tych osób stosowano przepisy dekretu PKWN z 4 XI 1944 r. o środkach zabezpieczających w stosunku do zdrajców Narodu Polskiego; wycofali swój wniosek rehabilitacyjny złożony w sądzie grodzkim

${ }^{29}$ Ibid.

${ }^{30}$ W Gdańsku do czasu zorganizowania specjalnego obozu „Troyl”, przeznaczonego dla Niemców, wobec których toczyło się postępowanie wyjaśniające, osadzano ich w Więzieniu Karno-Śledczym w Gdańsku. W krótkim czasie nastąpiło jego przeludnienie, co w połączeniu z panującymi w nim fatalnymi warunkami higienicznymi doprowadziło do wybuchu epidemii tyfusu (zob. AAN, MS, 7086, Sprawozdanie z działalności SSK w Gdańsku, [b.d.], k. 79).

${ }^{31}$ Przybywający lub świeżo osiedleni na tych terenach polscy osadnicy i ekspatrianci podejmowali niejednokrotnie różnego rodzaju działania, które miały umożliwić im przejęcie nieruchomości należącej do osoby podlegającej rehabilitacji czy weryfikacji. Mieszkania lub gospodarstwa zajmowano siłą lub przez fałszywe oskarżenie przedstawiciela miejscowej ludności autochtonicznej o różnego rodzaju przestępstwa czy też nieprzychylną Polsce postawę, doprowadzając do jego wysiedlenia za Odrę. Mieszkańcy Starogardu Gdańskiego jeszcze w czerwcu 1946 r. narzekali na utrudnienia w akcji rehabilitacyjnej powodowane przez fałszywe donosy kierowane do władz lokalnych, skutkujące pozbawieniem szeregu osób praw majątkowych i ochrony osobistej (zob. S. BYKowskA, op.cit., s. 247).

${ }^{32}$ Aby ukrócić podobne praktyki funkcjonariuszy UBP, naczelnikom obozów zabroniono przyjmowania osób przeznaczonych do osadzenia bez odpisu zarządzenia prokuratora SSK lub postanowienia właściwego sądu (zob. Instrukcja ministra bezpieczeństwa publicznego i ministra sprawiedliwości z dnia 18 VI 1945 r. w przedmiocie uporządkowania osób osadzonych w obozach, [in:] Księga bezprawia, s. 95-96). 
lub odwołali złożoną przez siebie deklarację wierności narodowi oraz demokratycznemu państwu polskiemu i rozpoczęli starania o wyjazd za granicęe $e^{33}$.

Uporządkowaniem spraw osób przebywających w obozach i więzieniach miały się zająć, powołane zgodnie z instrukcją Ministerstwa Bezpieczeństwa Publicznego (dalej cyt. MBP) i MS z 18 VI $1945 \mathrm{r}^{34}$, specjalne zespoły sądownicze. W ich skład wchodzili przedstawiciele MBP oraz sędziowie i asesorzy sądów powszechnych, a przewodniczył im prokurator specjalnego sądu karnego. Do zadań członków zespołu należało przesłuchanie osadzonych oraz zapoznanie się z wszelkimi zgromadzonymi w ich sprawach dokumentami. Jeżeli po zakończeniu tych czynności stwierdzali, że zebrane dowody nie uzasadniają dalszego przetrzymywania osadzonego, przedstawiali akta sprawy prokuratorowi SSK z wnioskiem o zwolnienie osoby, której dotyczyły. Ten z kolei, po konsultacji z przedstawicielem MBP, który miał stwierdzić, czy na osadzonym nie ciążą jeszcze inne zarzuty wyłączone spod kompetencji prokuratorów SSK i sądów okręgowych, zarządzał jego zwolnienie.

W przypadku gdy materiały zebrane w sprawie lub też zeznania osadzonego uzasadniały jego zatrzymanie, prowadzący badania wydawał zarządzenie o osadzeniu, a postępowanie kontynuowano. Gdy na miejscu nie było akt albo zgromadzony materiał nie był wystarczający do wydania wspomnianego zarządzenia ${ }^{35}$, protokół przesłuchania osadzonego lub jego akta przesyłano do UBP. Funkcjonariusze tego urzędu przeprowadzali lub uzupełniali dochodzenie w określonym terminie według wskazówek prokuratora lub sędziego, który wydał postanowienie o przesłaniu akt prokuratorowi SSK.

Gdyby okazało się, że jedynym zarzutem osadzonego jest przynależność do trzeciej lub czwartej grupy niemieckiej listy narodowej albo do Leistungs-Polen, osadzonego należało zwolnić. Natomiast w stosunku do osób mających w czasie okupacji drugą grupę lub trzecią „ze zrzeczeniem się odwołania” („mit Verzicht auf den Wiederruf") do grup narodowych uprzywilejowanych oraz do trzeciej i czwartej grupy na obszarach ustalonych w trybie artykułu 8 ustawy o wyłączeniu ze społeczeństwa polskiego wrogich elementów należało po zastosowaniu aresztu zapobiegawczego bez przesyłania akt UBP przekazać ich sprawy do sądu grodzkiego. Odpisy postanowień i zarządzeń powinny zostać przekazane kierownictwu obozu w celu załączenia do akt osobowych osadzonego i zaznaczenia w nich, że osadzony pozostaje do dyspozycji prokuratora SSK.

${ }^{33}$ Wyłączone spod dobrodziejstw ustawy „majowej” były także osoby, które zostały wpisane do drugiej, trzeciej lub czwartej grupy na wyraźną własną prośbę, a po otrzymaniu jednej z tych grup wykazywały się aktywną działalnością na korzyść okupanta, brały udział w prześladowaniu ludności polskiej czy żydowskiej, ewentualnie dopuściły się innej przestępczej działalności wobec narodu i państwa polskiego. Wobec takich osób prokurator SSK wszczynał dochodzenie o zbrodnie z dekretu „sierpniowego”, zob. K. BogUCKI, Organizacja, s. 46-47.

${ }^{34}$ Instrukcja ministra bezpieczeństwa publicznego i ministra sprawiedliwości z dnia 18 VI 1945 r. w przedmiocie uporzadkowania osób osadzonych w obozach, [in:] Księga bezprawia, s. 95-96.

${ }^{35} \mathrm{Jak}$ również w przypadkach, kiedy zebrany materiał wskazywał na to, że postanowienie o osadzeniu w obozie powinno być wydane w trybie artykułu 16 ustawy o wyłączeniu ze społeczeństwa polskiego wrogich elementów lub gdy osadzony popełnił przestępstwo przewidziane w dekrecie o karze dla zbrodniarzy faszystowsko-hitlerowskich (zob. ibid.). 
Z chwilą wydania postanowienia lub zarządzenia wobec osadzonego w obozie jego sprawa przechodziła do dyspozycji prokuratora SSK. O każdym przeniesieniu osadzonego do innego obozu lub więzienia naczelnik obozu musiał powiadamiać prokuratora SSK lub przewodniczącego SSK, któremu sprawa została przekazana. Zawiadomienia powinny się znajdować w aktach personalnych osadzonego. UBP po otrzymaniu protokołu przesłuchania lub akt sprawy osadzonego powinien bezzwłocznie przeprowadzić lub uzupełnić dochodzenie i bez względu na jego wynik przesłać następnie akta prokuratorowi SKK, od którego otrzymał polecenie, albo wskazanemu przezeń prokuratorowi lub sądowi. Po otrzymaniu akt sprawy prokurator SSK w zależności od wyniku dochodzenia mógł wydać nakaz lub zarządzenie zwolnienia osadzonego, które przesyłano do obozu w celu wykonania, albo wnieść akt oskarżenia do SSK. Mógł również przesłać je do sądu grodzkiego i dołączyć jako materiał uzupełniający do sprawy rehabilitacyjnej.

Na terenie Pomorza Gdańskiego uporządkowaniem spraw osób przetrzymywanych w obozach zajmowali się początkowo członkowie tzw. komisji filtracyjnej, organu dochodzeniowego powołanego przez szefa Wojewódzkiego Urzędu Bezpieczeństwa Publicznego (dalej cyt. WUBP) w Gdańsku, ppłk. Grzegorza Korczyńskiego. W jej skład weszli m.in. wiceprokurator SSK Rafał Kaniewicz, który razem z sędzią SSK w Gdańsku Zygmuntem Rossowskim, przedstawicielami MBP, funkcjonariuszami WUBP w Gdańsku oraz dwoma przedstawicielami Głównej Komisji Badania Zbrodni Niemieckich w Polsce mieli przeprowadzić postępowanie wyjaśniające wobec blisko 3000 osób znajdujących się w więzieniach i obozach na terenie województwa gdańskiego, które zostały wcześniej zatrzymane przez organa sowieckiego wojskowego wymiaru sprawiedliwości i w połowie maja $1945 \mathrm{r}$. przekazane do dyspozycji polskich władz. W przypadku ujawnienia przestępstw z dekretu „sierpniowego” uczestniczący w komisji prokurator specjalnego sądu karnego wszczynał dochodzenie i nadzorował przebieg czynności dochodzeniowych wykonywanych przez funkcjonariuszy UBP. Do czasu przybycia wydzielonej grupy organizacyjnej na czele z prokuratorem S. Stachurskim, której zadaniem było zorganizowanie SSK i Prokuratury SSK w Gdańsku, kilkadziesiąt spraw było już przygotowanych do sporządzenia aktów oskarżenia ${ }^{36}$.

W lipcu i sierpniu 1945 r. procedurę wyjaśniania sytuacji osób osadzonych w obozach musiano wstrzymać ze względu na szalejącą w gdańskim więzieniu epidemię tyfusu. Akcja weryfikacyjna ruszyła ponownie 19 IX $1945 \mathrm{r}^{37} \mathrm{Na}$ czele zespołu mającego wizytować obozy dla ludności niemieckiej mieszczące się na

${ }^{36}$ K. Bogucki, Ściganie, s. 184-185, 192.

${ }^{37}$ Archiwum Państwowe w Gdańsku, Oddział w Gdyni, Prokuratura Sądu Okręgowego w Gdyni, sygn. 588, Pismo do prokuratora SO w Gdyni, 10 IX 1945 r., k. 50. W jednym ze swoim okresowych sprawozdań dla Ministerstwa Sprawiedliwości S. Stachurski stwierdził, że akcję weryfikacyjną wznowiono dopiero na początku października. „Mimo zorganizowania zespołu sądowniczego do przesłuchania, przystąpić do pracy nie mogłem z powodu kwarantanny tyfusowej w więzieniu, a później w obozie. Kwarantanna zakończyła się w początkach października i wtedy przystąpiłem do pracy”, zob. AAN, MS, sygn. 7086, Sprawozdanie z działalności SSK w Gdańsku, [b.d.], k. 79. 
terenie podległym jurysdykcji SSK w Gdańsku stanął tym razem prokuratur gdańskiego SSK S. Stachurski. W pierwszym rzędzie przystąpiono do przesłuchiwania osób przebywających w gdańskim więzieniu bez jakichkolwiek sankcji. Niestety okazało się, że dla wielu z nich były to działania spóźnione, ponieważ 81 osób spośród 158, których sprawy rozpatrywano w pierwszej kolejności, zdążyło do tego czasu umrzeć na tyfus. $Z$ pozostałych: 35 osób zwolniono, resztę spraw przekazano według właściwości ${ }^{38}$. W wyniku działań wspomnianych komisji z obozów na terenie całego kraju zwolniono w 1946 r. znaczną część osadzonych tam bez podstawy prawnej osób, a wobec pozostałych przygotowywano akty oskarżenia, które kierowano następnie do specjalnych sądów karnych ${ }^{39}$.

Zgodnie z ustawą z 6 V 1945 r. o wyłączeniu ze społeczeństwa polskiego wrogich elementów osoby wpisane do trzeciej i czwartej grupy niemieckiej oraz grupy uprzywilejowanych Polaków (Leistungs-Polen) w zasadzie uzyskiwały przywrócenie pełni praw obywatelskich przed organami administracyjnymi pod warunkiem złożenia przysięgi wierności narodowi i demokratycznemu państwu polskiemu, jeżeli wpis nastąpił wbrew ich woli, wskutek przymusu, a swoją postawą w czasie okupacji potwierdzali polską odrębność narodową. Osoby wpisane do drugiej grupy niemieckiej i część osób pozostałych, którym odmówiono urzędowej rehabilitacji, musiały proces odzyskania obywatelstwa polskiego przeprowadzić sądownie. Ich sprawy mieli rozpatrzyć sędziowie sądów grodzkich ${ }^{40}$.

Sąd grodzki w sprawach o rehabilitację orzekał w składzie: jeden sędzia i dwóch ławników. Rozprawa toczyła się według przepisów kodeksu postępowania karnego z odmiennie unormowaną procedurą zaskarżenia. Uczestnikami postępowania byli zazwyczaj funkcjonariusze organów bezpieczeństwa publicznego ${ }^{41}$ oraz pro-

${ }^{38}$ Ibid.

${ }^{39} \mathrm{~W}$ marcu 1947 r. w obozach utworzonych na podstawie dekretu o środkach zabezpieczających przebywała jeszcze znaczna grupa osób oczekujących na decyzję prokuratora o wniesieniu aktu oskarżenia lub przywróceniu wolności. Ich liczebność szacowano na około 34000 osadzonych. Wielu innych pomimo pozostawania na wolności również nie miało uregulowanego statusu karnoadministracyjnego. Termin zakończenia trwającego w przypadku niektórych osadzonych od trzech lat stanu niepewności kilkakrotnie przedłużano, ostatecznie do 31 III 1948 r. W połowie 1948 r. większość internowanych została zwolniona. Znaczna część osób internowanych została jednak w latach 1947-1948 pozbawiona polskiego obywatelstwa i wysiedlona do Niemiec, zob. Grzegorz JAKUBOwSKI, Sadownictwo powszechne w Polsce w latach 1944-1950, Warszawa 2002, s. 189.

${ }^{40} \mathrm{~W}$ latach 1945-1946 sądy grodzkie w pierwszej instancji rozpatrzyły tysiące wniosków o przywrócenie obywatelstwa polskiego. Tylko do 1 VIII 1946 r. złożono w Polsce łącznie 223331 wniosków o rehabilitację, z czego do sierpnia 1946 r. zrehabilitowano 47089 osób. W przypadku 12955 wniosków sądy grodzkie rozpatrzyły negatywnie, 11691 wniosków załatwiono w inny sposób, a sprawy 151596 osób były w toku, zob. Informator sądowy na rok 1947/8, Warszawa 1947, s. 316.

${ }^{41}$ Powiatowe UBP na podstawie instrukcji dyrektora departamentu w MBP z 9 IV 1945 r. miały obowiązek wydelegowania funkcjonariusza UBP na rozprawę sądową dotyczącą wniosku urzędu lub osób cywilnych ubiegających się o rehabilitację. W wypadkach uwzględnienia wniosku o rehabilitację lub oddalenie wniosku UBP przewidzianego w $\S 4$ i 5 instrukcji wydelegowany funkcjonariusz bezpieczeństwa publicznego powinien w ciągu trzech dni złożyć kierownikowi UBP raport ze swoją opinią. Ten z kolei, jeżeli uznał orzeczenie sądu grodzkiego za niesłuszne, mógł złożyć w ciągu trzech dni kierownikowi WUBP raport ze swoją opinią. W przypadku gdy kierownik WUBP podzielał opi- 
kurator specjalnego sądu karnego uprawniony do wniesienia zażalenia na postanowienie rehabilitujące wnioskodawcę ${ }^{42}$. W takim przypadku sprawę ostatecznie rozstrzygał specjalny sąd karny. Sędziowie specjalnego sądu karnego na jawnym posiedzeniu badali okoliczności sprawy i w przypadku uznania braku przesłanek do rehabilitacji kierowali podsądnego do miejsca odosobnienia oraz orzekali przepadek mienia. Specjalnym sądom karnym powierzono także rozpatrywanie spraw oskarżonych o usuwanie majątku osób, których proces rehabilitacyjny trwał, lub pomaganie tym, którzy w terminie nie złożyli wniosku o rehabilitację albo których wniosek został odrzucony. Osoby te mogły zostać skazane na karę śmierci lub więzienia powyżej pięciu lat ${ }^{43}$.

Jeżeli w postępowaniu rehabilitacyjnym toczącym się przed sądem grodzkim zapadło pozytywne dla podsądnego postanowienie, było to jednoznaczne z przyznaniem mu pełni praw obywatelskich i wyłączeniem jego mienia spod ewentualnego zajęcia. Odrzucenie wniosku skutkowało orzeczeniem o pozbawieniu praw i przepadku mienia, fakultatywnie także majątku członków rodziny ${ }^{44}$. Jeżeli wnioskodawca pozostawał na wolności, sąd grodzki nakazywał jednocześnie umieszczenie go w miejscu odosobnienia. Od postanowień odmawiających rehabilitacji nie przewidziano środków odwoławczych ${ }^{45}$. Zaplanowano także trzeci rodzaj rozstrzygnięcia w postępowaniu rehabilitacyjnym. Badający zachowanie wnioskodawcy w czasie wojny oraz korzyści odniesione z tytułu wpisu na niemiecką listę narodową sąd grodzki został uprawniony do orzekania o ograniczonej rehabilitacji. W następstwie tego postanowienia część praw obywatelskich ulegała zawieszeniu na okres do pięciu lat, wymierzano grzywnę lub zasądzano przepadek części albo całości mienia podsądnego ${ }^{46}$.

nię kierownika powiatowego UBP, mógł się zwrócić natychmiast do prokuratora właściwego sądu specjalnego, przedstawiając odpowiednie dowody celem spowodowania odwołania i zastosowania artykułu 14 dekretu z 28 II 1945 r., zob. Instrukcja dyrektora departamentu w MBP z 9 IV 1945 r., [in:] Ksiega bezprawia, s. 84-87. Polaków bez tzw. udziału krwi niemieckiej nie wpisywano na DVL, co najwyżej byli zaliczani do grona Leistungs-Polen (czyli aktywnie pracujących Polaków, „wydajnych” Polaków). Niemcy uważali tych ludzi za pracujących dla dobra Rzeszy i dlatego zostali oni uprzywilejowani lepszą płacą i pracą oraz dodatkowymi przydziałami żywnościowymi.

${ }^{42} \mathrm{~W}$ procesie zaskarżenia decyzji podjętych przez sąd grodzki zdarzały się czasem nadużycia ze strony personelu specjalnych prokuratur karnych. Do takiej sytuacji doszło m.in. w Gdańsku, gdzie w wyniku interwencji w proces weryfikacji sekretarza prokuratury Władysława Blusa na podstawie nieprawdziwych zarzutów została uwięziona Małgorzata Szulc, do której opuszczonego mieszkania natychmiast wprowadził się wspomniany Blus, zob. S. BYкоwsKA, op.cit., s. 318.

${ }^{43}$ A. Machnikowska, op.cit., s. 268.

${ }^{44}$ Według przewodniczącego SSK w Gdańsku liczba wypadków odrzucenia wniosku o rehabilitację przez poszczególne sądy wynosiła od 5 do 25\%, zależnie od stopnia nasilenia w poszczególnych okręgach przymusu ze strony okupanta, zob. AAN, MS, sygn. 7086, Sprawozdanie z działalności SSK w Gdańsku, [b.d.], k. 77v.

${ }^{45}$ G. JaKUBOWSKi, op.cit., s. 189.

${ }^{46}$ A. Machnikowska, op.cit., s. 275. Zabezpieczenie majątku tych osób należało do właściwych urzędów skarbowych, którym niezbędnej pomocy mieli udzielić kierownicy miejscowych UBP. W nagłych wypadkach organy bezpieczeństwa publicznego miały prawo tymczasowo zabezpieczyć majątek i niezwłocznie zawiadomić o tym właściwy urząd skarbowy. Zob. Instrukcja dyrektora departamentu w MBP z 9 IV 1945 r., [in:] Księga bezprawia, s. 84-87. 
Na wyzwolonych spod niemieckiej okupacji terenach byłego Okręgu Rzeszy Gdańsk-Prusy Zachodnie sprawy rehabilitacyjne miały szczególną wymowę, po-

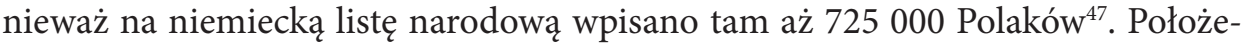
nie prawne tej grupy ludności stało się korzystniejsze po wejściu w życie ustawy z 6 V 1945 r. Wcześniej ustawodawca, nie orientując się w systemie polityki narodowościowej władz niemieckich, m.in. w odmiennych przepisach obowiązujących w Generalnym Gubernatorstwie i na ziemiach przyłączonych do Rzeszy, a także w wewnętrznym zróżnicowaniu tych ostatnich, wprowadził ostre represje, których zastosowanie na tych terenach praktycznie uniemożliwiłoby funkcjonowanie całych społeczności lokalnych ${ }^{48}$. Dopiero z czasem władze, zorientowawszy się w specyfice tego zagadnienia na ziemiach wcielonych do Rzeszy, zmienily swoje zapatrywania na tę kwestię. Potwierdzają to słowa Bolesława Bieruta, który 21 I 1945 r. na posiedzeniu Rządu Tymczasowego stwierdził: „O ile tutaj [w Generalnym Gubernatorstwie - D.B.] najczęściej na volksdeutschów zapisywały się elementy zdradzieckie, to tam [na ziemiach wcielonych do Rzeszy - D.B.] przeważnie ludzie ratujący się przed represjami" ${ }^{49}$.

Nie tylko ustawodawca nie był zorientowany w zagadnieniach polityki narodowościowej. Sędziowie mający rozstrzygać sprawy rehabilitacyjne, pochodzący bardzo często z innych części Polski, również niewiele o tym wiedzieli ${ }^{50}$. Świadczy o tym sytuacja, jaką przytoczył w swoim sprawozdaniu dla ministra sprawiedliwości pierwszy prezes Sądu Apelacyjnego w Gdańsku ${ }^{51}$ Franciszek Bar: „W pewnym miasteczku Wybrzeża został zwołany wiec w celu omówienia zagadnienia rehabilitacji na marginesie praktyki miejscowego sędziego grodzkiego. Sędzia, którego orzeczenia miały być krytykowane, poszedł na wiec i po kilku przemówieniach, z których jedno dało podstawę do wszczęcia przez prokuratora sprawy karnej

${ }^{47}$ A. Machnikowska, op.cit., s. 273.

${ }^{48}$ Jak słusznie zauważył S. Salmonowicz, fakt, że procedury rehabilitacyjne czy weryfikacyjne dotyczyły głównie ludności wsi i małych miasteczek pozbawionej z reguły pomocy prawnej, bardzo często powodował, że stawały się one ofiarami różnego rodzaju nadużyć czy też niekorzystnych dla nich rozstrzygnięć prawnych, zob. S. SALMONOwICZ, op.cit., s. 272.

${ }^{49}$ Cytat za: Leszek Olejnik, Zdrajcy narodu? Losy volksdeutschów w Polsce po II wojnie światowej, Warszawa 2006, s. 88.

${ }^{50}$ Trudnościom z interpretacją obowiązującego prawa towarzyszyła krytyka treści orzeczeń przez organy administracyjne, które do tego celu wykorzystywały również prasę. Nie uwzględniając uwarunkowań konkretnych spraw i sprowadzając cel postępowania do ukarania członków narodu byłych prześladowców, zarzucano sędziom zbyt łagodne ocenianie osób ubiegających się o potwierdzenie swojego polskiego obywatelstwa. Część oskarżeń miała jednak pozorowaną podstawę, odwracając uwagę od sprzecznych z prawem rozporządzeń majątkiem osób podlegających procedurze rehabilitacji, zob. A. Machnikowska, op.cit., s. 275.

${ }^{51}$ Teoretycznie apelację gdańską powołano dopiero w 1949 r., jednak praktycznie, mimo braku powołującego ją aktu normatywnego, funkcjonowała ona od lipca 1945 r. Podporządkowano jej tereny Pomorza Gdańskiego i Zachodniego, a w jej skład wchodziły okręgi sądowe podległe właściwości terytorialnej sądów okręgowych w Gdańsku, Gdyni, Elblągu, Słupsku, Szczecinie, Koszalinie i Wałczu. Szerzej zob. G. JAкUвоwsKi, op.cit., s. 104-113. Właściwość terytorialna SSK w Gdańsku obejmowała apelację gdańską oraz olsztyńską, dla której nie zorganizowano odrębnego SSK. 
o zniesławienie czy obrazę sądu, zabrał głos i wypowiedział jedno zdanie dla nas prawników zupełnie niewinne, które wywołało burzę okrzyków, wymysłów i gwizdów, że przewodniczący na żądanie przedstawiciela MO zmuszony był odebrać głos niefortunnemu mówcy. Ów sędzia powiedział: pod względem prawnym nie widzę różnicy między sytuacją należących do drugiej czy do trzeciej grupy listy niemieckiej. Nie orientował się czy też nie liczył się z faktem, iż sala wypełniona była przedstawicielami trzeciej grupy - rdzennymi Kaszubami, przeważnie bez ich zgody zniemczonymi przez okupanta, dla których porównanie z członkami drugiej grupy było czymś obraźliwym" ${ }^{52}$.

Do połowy 1946 r. do wszystkich sądów grodzkich w Polsce wpłynęło ponad 220000 wniosków o rehabilitację $e^{53}$. Liczba rozpoznawanych spraw oraz często jednostkowa obsada tych sądów spowodowały w stosunkowo krótkim czasie powstanie znacznych zaległości. Sprawy te stały się także jednym z tematów zjazdów oraz konferencji sędziów i prokuratorów. Ich uczestnicy omawiali m.in. liczne problemy prawne związane $\mathrm{z}$ nieuwzględnieniem $\mathrm{w}$ nowych przepisach skomplikowanych stanów faktycznych oraz z nachodzeniem zakresów norm kilku aktów prawnych regulujących sprawy odpowiedzialności z tytułu statusu narodowościowego ${ }^{54}$.

Jedna z takich konferencji odbyła się 14 VI 1946 r. w gmachu Sądu Apelacyjnego w Gdańsku. Celem, jaki postawili sobie jej organizatorzy, było „nawiązanie bliższego kontaktu pomiędzy sądownictwem a społeczeństwem" "55. Wzięli w niej udział przedstawiciele władz, urzędów, organizacji społecznych, partii politycznych, prasy oraz sądownictwa. Jednym z uczestników konferencji był także prokurator gdańskiego SSK S. Stachurski, który wygłosił referat o działalności specjalnych sądów karnych. Omówił w nim rolę dekretów regulujących zakres spraw poddanych właściwości specjalnych sądów karnych oraz zilustrował ruch spraw w SSK w Gdańsku, zaznaczając, że na powolne załatwianie tych spraw wpływają brak personelu sądowego oraz brak doświadczenia organów przeprowadzających dochodzenia. W dalszej części swojego przemówienia S. Stachurski podkreślił znaczenie współpracy Komisji Weryfikacyjnej w udzielaniu na żądanie Prokura-

${ }^{52}$ AAN, MS, sygn. 7433, Sprawozdanie Sądu Apelacyjnego w Gdańsku za maj 1946 r. Sprawy organizacyjno-gospodarcze, 5 XII 1946 r., k. 77.

${ }^{53}$ Najwięcej wniosków złożono w sądach apelacji katowickiej - 129 261, następnie w okręgu apelacji poznańskiej - 38416 oraz toruńskiej - 22 054. Najmniej w sądach grodzkich okręgu lubelskiego i wrocławskiego - odpowiednio 263 i 231. Postanowieniem rehabilitującym wnioskodawcę zakończyło się 78,5\% spraw. Prokuratorzy złożyli 2721 zażaleń, z których specjalny sąd karny uwzględnił 26\% rozpoznanych spraw, zob. Informator sądowy, s. 316-317; Andrzej PAsek, Przestępstwa okupacyjne w polskim prawie karnym z lat 1944-1956, Wrocław 2002, s. 123.

${ }^{54}$ Problem osób, które mimo niemieckiego obywatelstwa lub wpisu na listy zachowały polską odrębność, poruszano na zjazdach sądownictwa m.in. apelacji śląskiej, który odbył się w Katowicach w dniach 20-21 X 1945 r., zob. Andrzej DĄBrowski, Cel osiagnięty, [in:] Pamiętniki prawników. Wybór prac nadesłanych na konkurs pod nazwa „Pamiętniki prawników. Wspomnienia z 25 lat Polski Ludowej", Warszawa 1969, s. 130-131.

${ }^{55}$ Edmund Plebańczyк, Konferencja społeczna w Gdańsku, Demokratyczny Przegląd Prawniczy, 1946, nr 8, s. 26. 
tury SSK w Gdańsku informacji o okupacyjnej działalności politycznej osób, co do których wpłynęły różne anonimowe i nierzadko fałszywe doniesienia. S. Stachurski stwierdził również, że w większości orzeczeń sądów grodzkich w sprawach rehabilitacyjnych, zaskarżonych przez gdańską prokuraturę specjalną, SSK w Gdańsku zatwierdzał je, co dowodzi wnikliwego rozpatrywania tych spraw przez wspomniane sądy ${ }^{56}$.

Na terenie apelacji gdańskiej do 1 VIII 1946 r. złożono 14957 wniosków o rehabilitację, który to wynik umiejscowił ją na czwartej pozycji spośród wszystkich dziewięciu apelacji. Do sierpnia 1946 r. zostało zrehabilitowanych 4528 osób, a w przypadku 611 sąd nie uwzględnił wniosku o rehabilitację. Wnioski 8371 osób były jeszcze rozpatrywane, a w przypadku 1447 postępowanie rehabilitacyjne załatwiono w inny sposób ${ }^{57}$. W przypadku pozytywnego zakończenia procedury rehabilitacyjnej osoby jej poddane przybywały ponownie do sądów w celu odzyskania mienia zajętego w czasie trwania postępowania, które w wielu przypadkach zostało wcześniej przez władze lokalne rozdzielone wśród osadników i repatriantów. Władze bardzo często nie czekając na rozstrzygnięcia sądowe lub je ignorując, traktowały część mienia rehabilitowanych jako opuszczone lub poniemieckie, pospiesznie rozparcelowując je na rzecz reformy rolnej i osadników albo włączając do zasobów nieruchomości państwowych. Uchylając się od negatywnych skutków tego rodzaju praktyk, utrudniano egzekucję orzeczeń o rehabilitacji przez kwestionowanie ich zasadności ${ }^{58}$.

Jeżeli chodzi o udział gdańskiej prokuratury i sądu specjalnego w procedurze rehabilitacyjnej, to w 1945 r. Prokuratura SSK w Gdańsku wszczęła 1486, a w 1946 r. 1038 spraw przeciwko osobom (do 1 IX 1939 r. obywatelom polskim), którym zarzucono zdradę narodu polskiego przez dobrowolne zgłoszenie swej przynależności do narodowości niemieckiej i uzyskanie wpisu do drugiej, trzeciej lub czwartej grupy niemieckiej listy narodowej ${ }^{59}$. Ogółem, stosownie do przepisów ustawy z $6 \mathrm{~V}$ 1945 r. o wyłączeniu ze społeczeństwa polskiego wrogich elementów, procedurze karnej poddano 2524 osoby. W 554 sprawach (w 1945 r. - 275, a w 1946 r. - 279 spraw), stanowiących 21,8\% ogółu spraw wszczętych przez gdańską prokuraturę specjalną, dochodzenie umorzono ${ }^{60}$. W pozostałych podejrzani o kolaborację zostali zatrzymani i postanowieniem prokuratora SSK osadzeni w obozach ${ }^{61}$.

56 Ibid.

${ }^{57}$ Informator sadowy, s. 316.

${ }^{58}$ A. Machnikowska, op.cit., s. 275.

${ }^{59}$ Należy pamiętać, że sprawy te wpłynęły do Prokuratury SSK w Gdańsku z terenu dwóch apelacji: gdańskiej i olsztyńskiej. Niestety na podstawie zachowanych materiałów archiwalnych nie można stwierdzić, jaki procent z nich dotyczył osób z Pomorza Gdańskiego.

${ }^{60}$ Sprawy umorzone przekazywano następnie organom administracji państwowej stopnia podstawowego w celu przeprowadzenia postępowania rehabilitacyjnego w drodze postępowania administracyjnego.

${ }^{61}$ K. Bogucki, Organizacja, s. 46. 
Nadzór prokuratora SSK w Gdańsku nad postępowaniem rehabilitacyjnym znalazł swoje odbicie także w prowadzonych w gdańskim sądzie specjalnym repertoriach „Spec. V” oraz „Spec. V-W”. W pierwszym z nich rejestrowano zażalenia prokuratora SSK kierowane do SSK w Gdańsku na pozytywne dla wnioskodawcy postanowienie sądu grodzkiego o rehabilitacji oraz wnioski prokuratora o zawieszenie postępowania rehabilitacyjnego $\mathrm{w}$ danej sprawie przez sąd grodzki ${ }^{62}$. W drugim rejestrowano sprawy osób niezrehabilitowanych, dla których wynik sądowego postępowania rehabilitacyjnego był negatywny ${ }^{63}$. W przypadku tych osób sąd grodzki wydawał postanowienie o ich umieszczeniu w miejscach odosobnienia na czas nieokreślony, poddaniu przymusowej pracy, utracie praw publicznych i obywatelskich praw honorowych na zawsze oraz przepadku całego mienia na rzecz Skarbu Państwa. Nadzór nad wykonaniem postanowienia sądu grodzkiego należał do prokuratora specjalnego sądu karnego. Z przeprowadzonych przez K. Boguckiego badań wynika, że prokurator SSK wniósł do SSK w Gdańsku 453 zażalenia na pozytywne dla wnioskodawcy orzeczenia sądów grodzkich o rehabilitacji (72 zażalenia w 1945 r. i 381 w 1946 r.) ${ }^{64}$ oraz zażądał zawieszenia postępowania rehabilitacyjnego w 161 sprawach (wszystkie w 1946 r.) ${ }^{65}$.

Sprawami rehabilitacyjnymi w Prokuraturze SSK w Gdańsku zajmował się podprokurator R. Kaniewicz ${ }^{66}$. We wrześniu 1946 r. Nadzór Prokuratorski MS wszczął wobec niego postępowanie wyjaśniające w związku z podejrzeniem o czerpanie finansowych korzyści w zamian za interwencje w przebieg postępowania rehabilitacyjnego. Takie zarzuty wobec R. Kaniewicza wysunął ówczesny kierownik Wydziału Śledczego WUBP w Gdańsku Józef Bik, który stwierdził, że „Tryb życia v[ice] prokuratora Kaniewicza zmienił się w ostatnich czasach niesłychanie, nastąpił w nim kolosalny zwrot, to jest obecnie człowiek, który jest elegancko ubrany i posiada pieniądze. Dawniej było mu ciężko. Robił starania o przejście do Prokuratury Marynarki Wojennej w Gdyni, a gdy otrzymał zgodę, wówczas zrezygnował, należy więc przypuszczać, że obecne stanowisko opłaca mu się lepiej”. Niestety nie wiadomo, jak zakończyła się ta sprawa, ale dalsza kariera zawodowa

${ }^{62}$ Zdaniem Romana Wapińskiego na terenie województwa gdańskiego liczba osób zrehabilitowanych przez sądy grodzkie wynosiła 3511 osób, z czego 3505 (99,8\%) zrehabilitowanych przypadało na powiaty: gdyński, kartuski, kościerski, starogardzki, tczewski i wejherowski, zob. Roman WAPIŃSKI, Pierwsze lata władzy ludowej na wybrzeżu gdańskim, Gdańsk 1970, s. 70.

${ }^{63}$ Oddalenie wniosku rehabilitacyjnego mogło nastąpić np. w przypadku, gdy wnioskodawca nie udowodnił przed sądem, że do odpowiedniej grupy został wpisany wbrew swojej woli, zob. K. Bogucki, Organizacja, s. 49.

${ }^{64}$ Według Informatora sądowego do 1 VIII 1946 r. do SSK w Gdańsku wpłynęły 183 zażalenia prokuratura gdańskiego SSK na postanowienia sądów grodzkich, z której to liczby sąd utrzymał w mocy 34 postanowienia rehabilitacyjne, 6 zażaleń prokuratora nie uwzględnił, a w 143 przypadkach postępowanie trwało, zob. Informator sądowy, s. 317.

${ }^{65}$ K. Bogucki, Organizacja, s. 49.

${ }^{66}$ AAN, MS, sygn. 7086, Sprawozdanie z działalności Prokuratury SSK w Gdańsku, [b.d.], k. $76 \mathrm{v}-77$. 
R. Kaniewicza wskazuje na to, że została ona wyjaśniona na korzyść prokuratora gdańskiej prokuratury $\mathrm{SSK}^{67}$.

W latach 1945-1946 do gdańskiej prokuratury SSK wpłynęły łącznie 293 interwencje ( $34 \mathrm{w} 1945$ r. i 259 w 1946 r.) w postaci zbiorowych listów protestacyjnych, petycji, skarg i doniesień anonimowych na niesłuszne, zdaniem autorów interwencji, orzeczenia rehabilitacyjne. W pismach tych wyszczególniano zarzuty dotyczące przede wszystkim współpracy zrehabilitowanych z okupantem. Dowodzono ich wrogiego stosunku do społeczeństwa polskiego w czasie okupacji, wyszczególniano fakty mające świadczyć o tym, że osoby te zostały zrehabilitowane niesłusznie ${ }^{68}$.

Przewodniczący SSK w Gdańsku w jednym ze sprawozdań miesięcznych opisującym działalność kierowanej przez niego instytucji stwierdził, że: „sprawy rehabilitacyjne wymagają od sędziego olbrzymiej wnikliwości, dużego doświadczenia, znajomości psychiki ludzkiej i indywidualnego wczucia się w każdą sprawę". Jednakże, jak pisze w dalszej części sprawozdania: „W dotychczasowej praktyce spotykałem raczej szablonowe podejście do tych spraw. Sędzia grodzki, zazwyczaj człowiek młody może nawet inspirowany najlepszymi chęciami i zamiarami, nieposiadający jednakże dostatecznego doświadczenia życiowego, wyznacza na jedno posiedzenie spraw rehabilitacyjnych 15 do 20-tu. Już sama ilość wyznaczonych spraw nie daje gwarancji rozpatrzenia ich z potrzebną tym sprawom wnikliwością, jeśli się zważy, że w toku jednego posiedzenia mają być przesłuchani świadkowie i ogłoszone postanowienie $\mathrm{z}$ uzasadnieniem, $\mathrm{w}$ razie pozytywnego załatwienia wniosku. Poza tym zauważyłem, że postanowienia uwzględniające wnioski zawierają stereotypowe uzasadnienia, bite czy to na hektografach czy też przez kalkę na maszynie. Mówię w tej chwili o wypadkach, które miałem możność skontrolować. I gdyby nawet $w$ większości wypadków okazało się, że postanowienie uwzględniające wniosek rehabilitacyjny, jest pod względem merytorycznym słuszne, to jednak załatwianie wniosku postanowieniem bitym na szablonie nie odpowiada powadze sprawy. Zauważyłem ponadto, że czynnik obywatelski, czy społeczny sprawami rehabilitacji nie ze bardzo się interesuje. Odniosłem raczej wrażenie, że w sprawach tych zainteresowane są osoby, które również wniosek taki postawiły i osoby te stanowią gros publiczności na rozprawach sadowych. Jeśli w osiedlu pewnym 90 proc. mieszkańców wpisanych jest do drugiej grupy volkslisty, nie można się

${ }^{67}$ Archiwum Instytutu Pamięci Narodowej w Gdańsku, sygn. 321/46, Wyciąg ze sprawozdania ob. Bika Kierownika Wydziału Śledczego WUBP w Gdańsku, [b.d.], k. 7; Akta postępowania wyjaśniającego [b.d.], k. 6-38.

${ }^{68}$ Ustawa z 6 V 1945 r. o wyłączeniu ze społeczeństwa polskiego wrogich elementów w artykule 3 głosiła, że „kto wie o tym, iż obywatel państwa polskiego ubiegający się o rehabilitację wpisany został z własnej woli po dniu 31 VIII 1939 r. na obszarach Rzeczypospolitej Polskiej wcielonych przemocą przez okupanta do Rzeszy Niemieckiej oraz na obszarze byłego Wolnego Miasta Gdańska do trzeciej czy czwartej grupy niemieckiej listy narodowościowej i jego zachowanie się w tym okresie okupacji nie dało się pogodzić z polską odrębnością narodową - powinien zawiadomić o tym władze bezpieczeństwa publicznego lub prokuratora specjalnego sądu karnego". 
spodziewać, aby wnosiły one sprzeciwy, gdyż same zainteresowane są w uzyskaniu rehabilitacji”"69.

Józef Tarczewski zaproponował, aby do postępowania rehabilitacyjnego przymusowo wciągnąć związki zawodowe z nałożeniem na nie obowiązku przeprowadzenia w każdej indywidualnej sprawie dochodzeń i złożenia następnie swoich wniosków, umotywowanych bądź bezpośrednio na rozprawie, bądź też przed rozprawą, prokuratorowi specjalnego sądu karnego. Jego zdaniem związki zawodowe powinny być o każdym wszczętym postępowaniu rehabilitacyjnym zawiadamiane równocześnie z Prokuraturą SSK, dzięki czemu można by uniknąć wielu pomyłek stanowiących nieraz o życiu obywatela i jego rodziny. Poza tym uważał on, że ustawa o wyłączeniu ze społeczeństwa wrogich elementów jest zbyt rygorystyczna, ponieważ w razie odrzucenia wniosku o rehabilitację należało obligatoryjnie orzec umieszczenie w obozie odosobnienia na czas nieoznaczony. Według J. Tarczewskiego przepis ten „nie znajduje oddźwięku ani zrozumienia w społeczeństwie. Społeczeństwo domaga się zróżniczkowania kar zastosować się mających stosownie do przewinienia i traktowania każdej poszczególnej sprawy indywidualnie. Jeśli poczucie sprawiedliwości, społecznej - której wyrazem są ławnicy - zgodziłoby się w określonych wypadkach ukarać np. renegata zamknięciem go w obozie odosobnienia na pewien określony przeciąg czasu, i karę taką uważałoby za odpowiadającą przewinieniu, to jednakże to samo poczucie sprawiedliwości nie pozwala na usunięcie takiego osobnika na stałe ze społeczeństwa"70.

Jako przykłady spraw, które rozpatrywał SSK w Gdańsku, sędzia J. Tarczewski przytoczył dwie z nich: „[...] pierwszą zażaleniową od postanowienia sądu grodzkiego orzekającego rehabilitację byłego nauczyciela polskiego, osobnika cieszącego się znaczną popularnością w terenie, drugą karną, również b. obywatela polskiego, który jednakże od czasu wkroczeniu wojsk niemieckich stał się członkiem NSDAP i który po ocaleniu w dniu 20 VII 1944 r. Führera ofiarował na rzecz niemieckiego Czerwonego Krzyża kwotę 1000 RM. W pierwszym wypadku zmieniłem postanowienie sądu grodzkiego i zarządziłem zgodnie z przepisami ustawy umieszczenie wnioskodawcy na czas nieoznaczony w obozie odosobnienia, poddanie go przymusowej pracy, pozbawienie praw publicznych i honorowych praw obywatelskich na zawsze, tudzież konfiskatę całego jego majątku. W drugim wypadku orzekłem karę więzienia przez lat trzy z zaliczeniem aresztu tymczasowego. Te dwa orzeczenia nie znalazły pełnego zrozumienia w społeczeństwie, aczkolwiek opierały się w całości na obowiązujących przepisach prawnych. Społeczeństwo za tym domaga się zmienienia ustawy o wyłączeniu ze społeczeństwa wrogich elementów w tym kierunku, aby obligatoryjną karę umieszczenia w obozie odosobnienia przez czas nieoznaczony, zamienić na takąż karę od lat dwóch do czasu nieoznaczonego"71.

\footnotetext{
${ }^{69}$ AAN, MS, sygn. 7086, Sprawozdanie z działalności SSK w Gdańsku, [b.d.], k. 73.

${ }^{70}$ Ibid., k. 73-75.

${ }^{71}$ Ibid., k. 75.
} 
W drugiej połowie $1946 \mathrm{r}$. MS uznało, że sytuacja związana z potwierdzeniem lub nadaniem obywatelstwa polskiego na drodze sądowej zaczyna się stabilizować. Wydane w tym czasie akty prawne zmierzały do ostatecznego rozstrzygnięcia o odpowiedzialności karnej osób, które nie uzyskały rehabilitacji. Problem rozwiązano dwustopniowo. Pierwszy łączył się z wydaniem dekretu z 28 VI 1946 r. o odpowiedzialności karnej za odstępstwo od narodowości w czasie wojny 1939$1945^{72}$. Osoby, które nie przeszły pozytywnie procedury postępowania przed sądem grodzkim lub przebywały w obozach na mocy postanowienia specjalnego sądu karnego, poddano ponownej weryfikacji. Prokurator SSK sprawdzał okoliczności, w których doszło do wpisu na niemiecką listę narodową, kierując sprawę, $\mathrm{w}$ przypadku stwierdzenia przesłanek popełnienia przestępstwa, a początkowo także w zależności od miejsca zamieszkania w czasie wojny, albo do specjalnego sądu karnego, albo do sądu okręgowego orzekającego w składzie ławniczym ${ }^{73}$.

Ostatnim etapem legislacyjnych rozstrzygnięć kwestii rehabilitacji osób, które w czasie okupacji przyjęly jedną z grup niemieckiej listy narodowej, były przepisy umożliwiające pozbawienie polskiego obywatelstwa i wysiedlenie z kraju osób wykazujących swym zachowaniem niemiecką odrębność narodową. Dekret z 13 IX 1946 r. o wyłączeniu ze społeczeństwa polskiego osób narodowości niemieckiej ${ }^{74}$ przewidywał przede wszystkim wykorzystanie procedury administracyjnej inicjowanej wnioskiem organów bezpieczeństwa publicznego. Postępowanie przed sądem okręgowym w składzie ławniczym prowadzono na skutek żądania strony wnoszonego w terminie siedmiu dni od wydania orzeczenia administracyjnego. W posiedzeniach uczestniczyły strony postępowania oraz prokurator. Rozstrzygnięcie sądu nie podlegało zaskarżeniu ${ }^{75}$.

Jedną z przyczyn stopniowego wygaszania procedur karnych wobec osób, które zadeklarowały niemiecką lub uprzywilejowaną narodowość, była zmiana priorytetów politycznych. Z jeden strony starano się jak najszybciej przeprowadzić operację wydalenia tej grupy ludności z kraju, z drugiej, tonując stanowisko w kwestii surowych sankcji za zmianę przynależności narodowej i obywatelstwa, przenoszono uwagę, a wraz z nią określenie „zdrajców Narodu” na przeciwników politycznych. Po likwidacji specjalnych sądów karnych (17 XI 1946 r.) i uchyleniu dekretu z 4 XI 1944 r. o środkach zabezpieczających w stosunku do zdrajców Narodu oraz ustawy z 6 V 1945 r. o wyłączeniu ze społeczeństwa wrogich elementów jednolitą podstawą odpowiedzialności dla tej grupy czynów stały się przepisy dekretu z 28 VI 1946 r. o odpowiedzialności karnej za odstępstwo od narodowości

${ }^{72} \mathrm{DzU}$ z 1946 r., Nr 41, poz. 237.

${ }^{73}$ A. МаснniкowsKa, op.cit., s. 276.

${ }^{74}$ DzU z 1946 r., Nr 55, poz. 310.

${ }^{75} \mathrm{~W}$ sytuacji gdy osoba została wcześniej skazana prawomocnym wyrokiem za czyny związane z odstępstwem od narodowości, nie rozpoczynano jednak postępowania administracyjnego, a toczące się umarzano, zob. A. MaCHNikowsKA, op.cit., s. 277. 
w czasie wojny 1939-1945, którymi objęto terytorium całego krajü6. Wszystkie unormowane w nim czyny przeszły pod jurysdykcję sądów okręgowych ${ }^{77}$.

${ }^{76}$ Początkowo obowiązywał on jedynie na obszarze województwa śląsko-dąbrowskiego. Rozszerzenie mocy prawnej na resztę terytorium państwa nastąpiło na mocy rozporządzenia Rady Ministrów z 19 IX 1946 r., zob. DzU z 1946 r., Nr 53, poz. 300.

77 Zrealizowano tym samym zgłaszany od dawna przez sędziów postulat sprecyzowania podstawy materialnej odpowiedzialności za działania noszące znamiona odstępstwa od narodowości. Przed wejściem w życie dekretu z 28 VI 1946 r. czyn ten mógł być kwalifikowany zarówno z artykułu 100 kodeksu karnego i rozpoznawany przez sąd okręgowy w składzie zawodowym, jak i z artykułu 100 kodeksu karnego Wojska Polskiego, a także stanowić przedmiot rozpoznania przez specjalny sąd karny, zob. A. Machnikowska, op.cit., s. 277.

\author{
DIE BETEILIGUNG DES SPEZIELLEN STRAFGERICHTS IN DANZIG \\ UND SEINER STAATSANWALTSCHAFT IM PROZESS DER VERIFIKATION \\ UND REHABILITIERUNG DER BEVÖLKERUNG POMERELLENS \\ IN DEN JAHREN 1945-1946
}

Zusammenfassung

Schlüsselbegriffe: Deutsche Volksliste, Polnische Nachkriegsgerichtsbarkeit, Staatliche Dekrete, Aussiedlung der deutschen Bevölkerung, sog. Verräter am Polnischen Volk

Das Ziel der Arbeit liegt in der Publikation der Ergebnisse zum Speziellen Strafgericht (SSK) und zur Staatsanwaltschaft des SSK in Danzig im Prozess der Verifikation und Rehabilitierung der Bevölkerung Pomerellens in den Jahren 1945-1946. In den bislang veröffentlichten Arbeiten zu den Spezialgerichten oder zur Rehabilitierung und Verifikation der polnischen Bevölkerung nach dem Ende des Zweiten Weltkriegs wird die Rolle der Spezialgerichte und der Staatsanwaltschaften nur in geringem Maße berücksichtigt oder ganz übergangen. Die Erforschung dieses Problems ist insofern wesentlich, als allein im Reichsgau Danzig-Westpreußen bis zu 725.000 Polen in die Deutsche Volksliste eingetragen wurden, von denen sich die meisten nach dem Kriegeinem der oben genannten Prozesse unterzogen.

In Bezug auf die Beteiligung des Speziellen Strafgerichts in Danzig und seiner Staatsanwaltschaft an der Verifikation und Rehabilitierung der Bevölkerung Pommerellens, so leitete die Staatsanwaltschaft des SSK im Jahre 1945 insgesamt 1486, und im Jahre 1946 - 1038 Verfahren gegen Personen ein, denen Verrat am Polnischen Volk vorgeworfen wurde, da sie freiwillig ihre Zugehörigkeit zur deutschen Bevölkerung deklariert und eine Eintragung in die zweite, dritte oder vierte Kategorie der deutschen Volksliste erlangt hätten. Insgesamt wurden gemäß dem Gesetz vom 6. Mai 1945 über den Ausschluss feindlicher Elemente aus der polnischen Bevölkerung 2524 Personen einem Strafverfahren unterworfen. In 554 Fällen, entsprechend 21,8\% der Gesamtzahl der von der Danziger Spezialstaatsanwaltschaft eingeleiteten Verfahren, wurde das Verfahren eingestellt. In den übrigen Fällen wurden die der Kollaboration verdächtigen festgenommen und per 
Beschluss der Staatsanwaltschaft des SSK in Lagern inhaftiert. Der Staatsanwalt des SSK in Danzig wandte sich zudem in 453 Fällen an das SSK in Danzig mit Beschwerden über die für die Antragsteller positive Beurteilung der Anträge auf Rehabilitierung durch die Amtsgerichte und forderte in 161 Fällen die Aussetzung des Rehabilitierungsprozesses. Nach der Auflösung der Speziellen Strafgerichte (17. November 1946) wurden alle Prozesse mit strafrechtlichem Inhalt wegen Abwendung von der polnischen Nationalität während des Zweiten Weltkrieges der ausschließlichen Jurisdiktion der Bezirksgerichte unterstellt.

\title{
THE PARTICIPATION OF THE SPECIAL CRIMINAL COURT IN GDAŃSK AND THE PUBLIC PROSECUTOR'S OFFICE IN THE PROCESS OF THE VERIFICATION AND REHABILITATION OF THE POPULATION OF GDAŃSK POMERANIA IN THE YEARS 1945-1946
}

\begin{abstract}
Summary
Key words: the Deutsche Volksliste (German People's List), the Polish after-war judiciary system, national decrees, the relocation of the German population, the so called traitors of the Polish nation
\end{abstract}

The aim of the work is to publish the author's findings concerning the participation of the Special Criminal Court in Gdańsk and the Public Prosecutor's Office in the process of the verification and rehabilitation of the population of Gdańsk Pomerania in the years 1945-1946. In works hitherto published, researchers dealing with the special judiciary system or rehabilitation and verification of the Polish population after WWII omitted or examined very cursorily the role of special courts and prosecutor's offices in the processes mentioned above. It is essential to examine this problem due to the fact that only in the area of the Reich District Gdańsk-West Prussia as many as 725,000 Poles were registered with the Volkliste. Most of them underwent either of the processes discussed here.

As far as the participation of the Special Criminal Court in Gdańsk and the Public Prosecutor's Office in the process of the verification and rehabilitation of the population of Gdańsk Pomerania is concerned, in 1945 the Prosecutor's Office of the Special Criminal Court in Gdańsk initiated proceedings against 1486 people, and in 1946 against 1038 people. They were accused of treachery against the Polish nation by having been registered with the Volkliste in the second, third or fourth category. In total, 2524 people were brought to the criminal court according to the Law of 6 May 1945 concerning the exclusion of hostile elements from Polish society. 554 cases commenced by the Gdańsk Special Prosecutor's Office (which constituted $21.8 \%$ of the total number of cases) were redeemed. The rest of the accused were arrested and sent to camps following the decision of the prosecutor of the Special Criminal Court in Gdańsk, who also lodged complaints against the decisions of the municipal courts about the rehabilitation of 453 people; the prosecutor demanded the rehabilitation proceedings be suspended in 161 cases. After the special criminal courts had been abolished (17 Nov 1946) all cases concerning the renouncement of Polish nationality during WWII fell under the jurisdiction of district courts. 